\title{
座り心地主観評価における短時間評価と使用後評価の違い
}

\author{
○白石 光昭（千葉工業大学）
}

\section{The relation between short-term evaluation and evaluation after seat a week on office seat comfort}

\section{Mitsuaki SHIRAISHI (Chiba Institute of Technology)}

\section{1. 目的}

オフィスチェアの座り心地を主観評価で調べる 際には，座った直後（10分以内が多い）のアンケ 一ト調査を中心に行われることが多い（以下，短 時間評価と呼ぶ)。しかし一般のユーザは，椅子 に座りながら様々な行為を行い，そして様々な姿 勢をとり，それら一連の使用状況をもとに，総合 的に椅子を評価するものと考えられる。つまり、 短時間評価では、使用後の評価と同じ結果が得ら れているか疑問が残る。しかし，使用後評価は， 調査時間がかかる，業務への支障等被験者への負 荷も考慮せねばならず，実際の実施は難しい。

一般的に短時間評価は使用後評価を表している と仮定し，上記のように短時間評価を中心に座り 心地評価が行われていると考えられるが，このた めには短時間評価は使用後評価をどの程度反映し ているかを把握しておく必要がある。しかし，才 フィスチェアの座り心地に関する既往研究では, 5〜10分程度使用して評価をする短時間評価が中 心であり，長期間使用後の評価との関係を調べた ものは見受けられない。

そこで，本研究ではオフィスチェアを対象にア ンケート調査による短時間評価と使用後評価の比 較を行い，短時間評価が使用後評価をどの程度反 映しているのかを明らかにする。なお，本研究で は短時間を座って5〜10分以内，使用後を1週間 （月〜金の 5 日間）後と設定した。

\section{2. 方法}

従来から使用されてきた調査項目と新たに追加 した項目をもとにアンケート項目を設定した（計 33問）。被験者には調査用の椅子を使用してもら い，椅子をアンケートにより主観評価（5段階評 価）してもらった。調査用の椅子の割当ては図 1 の通りであり， 1 脚につき 1 週間（月〜金），無
作為に順番を決めた椅子を使用してもらった。調 查用の椅子を使用した次の週は，評価の前提条件 を一定とするため各被験者が通常使用している椅 子を使用してもらった（調查は隔週となる）。

調査用のオフィスチェアについては，座り心地 の評価に影響が強いと考えられる姿勢変化の機能 が異なる椅子を，大手メーカー 1 社から 5 脚選出 した（図 2 )。これは，姿勢変化機能が異なって も同じか㳪かを確認し，またメーカー間の品質の ばらつきを考慮しないためである。被験者はA高 専の事務職員で，22～58才の23名（男性12名，女 性11名）を2グループに分けて実施した。なお, 全員が週3日以上，1日に5時間以上椅子を使用し ていた。

\begin{tabular}{|c|c|c|c|c|c|c|}
\hline \multirow{4}{*}{ 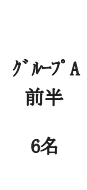 } & $\varnothing$ & 8 & 8 & 3 & 8 & \\
\hline & 被䀫者 & No. 4 & 通常 & No. 2 & 通常 & \\
\hline & 8 & 8 & 8 & 8 & 8 & \multirow{2}{*}{$\ldots$} \\
\hline & 被騟者 & No. 2 & 通常 & No. 5 & 通常 & \\
\hline & & 第 1 週 & 第 2 週 & 第 3 週 & 第4週 & 第12週 \\
\hline & & (月～金) & (月～金) & (月～金) & (月～金) & \\
\hline \multirow{3}{*}{$\begin{array}{c}\text { グN-プ A } \\
\text { 後半 }\end{array}$} & 8 & 8 & 8 & 8 & 8 & \\
\hline & 被跲者D & 通常 & №. 4 & 通常 & No. 2 & \\
\hline & $\triangle$ & 8 & $\vec{z}$ & \& & 7 & \multirow{2}{*}{$\ldots$} \\
\hline 6名 & 被験者A & 通常 & No. 2 & 通常 & No. 5 & \\
\hline
\end{tabular}

図 1 実験手順

\begin{tabular}{|lclc|}
\hline & 発売年 & 座·背の傾斜について & 背の固定 \\
\hline No.1 & 1961 & 背のロッキング,,背の首振り & 不可 \\
\hline No.2 & 1978 & 背の首振り(角度調整は可) & 可 \\
\hline No.3 & 1980 & 連動リクライイング & 可 \\
\hline No.4 & 1987 & 連動ニーチルトリクライニング & 不可 \\
\hline No.5 & 2000 & 連動アンクルチルリリラライング & 可 \\
\hline No.6 & 2002 & 連動アンクルチルトリクライニング & 可 \\
\hline
\end{tabular}

困 2 実験用いすの特徴 


\section{3. 結果}

本研究では，各質問項目の平均值と標準偏差に 注目し，それぞれの（使用後評価一短時間評価） の值を求めた（表 1 ）。表中の網掛けは，平均值 で被験者の $20 \%$ （5 人）が 1 段階評価を下げた場 合の数值低下があった質問項目を，標準偏差では 被験者の $20 \%$ （5人）がばらついた場合の数值の 上昇があった質問項目である。評価の平均值が低 下寸ることは当然悪いと言えるが，標準偏差が上 昇することも評価にバラツキが増加することであ り，これも問題があると考えた。

表 1 にあるように（網掛けしてある質問項目）, 6 脚の内 4 脚以上の椅子で評価が低下した質問 (平均值または標準偏差が悪化) は, 質問2, 3(2), 12，132)，15，16，19，20，25の9項目であった。 同様に，6脚の内3脚の椅子において評価が低下 した質問は，質問1，9，9(2)，10(2)，13，14(2)， 18の7項目であった。つまり，全質問の約半分に あたる16項目の質問で評価が低下していた。この ような傾向から，短時間評価は使用後評価を正確 には表しておらず，使用後評価よりも若干高い評 価を表している可能性が考えられる。

また，各質問項目において平均的な低下率を求 めたが (表右欄), 質問項目によって異なり, 平 均值は数\%～40\%程度とバラツキがあった。ただ， 座面に関連する質問、背もたれに関連する質問、 傾斜機構に関連する質問に分けてみると、座面関 連で約15\%、背もたれ関連で約 $30 \%$ 、傾斜機構関

表 3 アンケート結果
連で約15\%となり，背もたれ関連の質問項目の低 下率が低いことがわかった。これに対し，標準偏 差の変動は少なかった。一例として，質問10（腰 部のフィット感) について平均值と標準偏差を軸 として図 3 を作成した。5 脚の椅子は平均值が低 下している。内 3 脚は標準偏差の值も低下し，使 用後評価のバラツキが少なくなっている。

\section{4.まとめ}

事務用椅子を対象に，座り心地の主観評価を短 時間のアンケート調査で調べる場合，一定の期間 使用された後の評価には差があり, 使用後の評価 が若干下がることがわかった。

今後の課題として, 短期評価から実際の評価を 推測できるモデル構築があるが，さらに多くの椅 子を対象に物理量の検討も含め, 調査を行う必要 があると考えている。

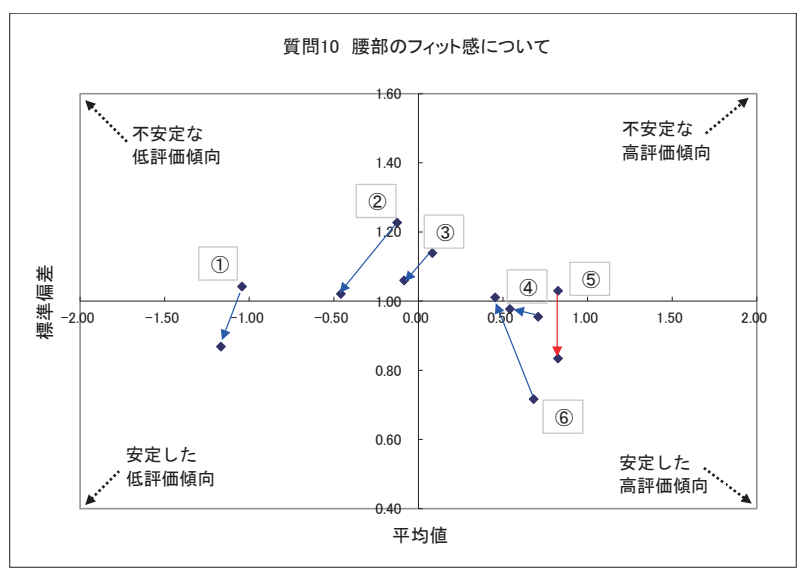

図 3 腰部のフィット感の評価の差（質問10）

\begin{tabular}{|c|c|c|c|c|c|c|c|c|c|c|c|c|c|c|c|c|c|c|c|c|c|}
\hline & & & No. 1 & & & No.2 & & & No.3 & & & No.4 & & & No. & & & No.6 & & \begin{tabular}{|l} 
低下率. \\
\end{tabular} & 上昇率 \\
\hline 質問項目 & 質問No & 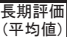 & $\begin{array}{c}\text { 平均間 } \\
\text { 差 }\end{array}$ & 標準偏羞 & 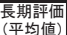 & $\begin{array}{l}\text { 平均間。 } \\
\text { 差。 }\end{array}$ & 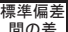 & $\begin{array}{l}\text { 長期評伻価 } \\
\text { 平均值) }\end{array}$ & 平均間 & 橒準偏着 & 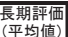 & 平均間。 & 標準偏差 & 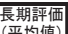 & 平均㹃 & 慓隻偏着 & 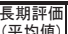 & 平均間 & $\mid$ & 平均間の & 蕒準偏着着 \\
\hline 追随性 & 1 & 0.46 & & C & $\frac{10+3 y}{-0.33}$ & & 间(0)原 & 0.50 & & 間の麦 & 0.75 & 立 & B & $\frac{1.35}{1.35}$ & 左 & [1]日0) & 0.82 & $\frac{\text { 左 }}{D}$ & C & $\begin{array}{ll}\frac{5}{5} \\
-17.7\end{array}$ & 2.34 \\
\hline 屈の位置ずれ & 2 & 0.00 & $\mathrm{C}$ & $\mathrm{B}$ & 0.25 & $\mathrm{C}$ & A & 0.79 & & $\mathrm{~B}$ & 0.67 & & $\mathrm{~B}$ & 0.61 & $\mathrm{D}$ & $\mathrm{D}$ & 0.50 & $\mathrm{D}$ & $\mathrm{C}$ & -49.2 & -5.02 \\
\hline 大腿部のあたり & 3 & -0.17 & & $\mathrm{D}$ & 0.08 & $\mathrm{C}$ & & 0.00 & & $\mathrm{~A}$ & -0.17 & & & -0.09 & & & -0.14 & & $\mathrm{~B}$ & -69.6 & -6.97 \\
\hline 自分にとって & $3(2)$ & -0.42 & C & & 0.08 & & C & 0.38 & & & 0.33 & $\mathrm{C}$ & C & 0.65 & C & $\mathrm{B}$ & 0.68 & & C & -19.1 & 5.23 \\
\hline シャツのめくり上がり & 4 & -0.42 & $\mathrm{C}$ & & 0.13 & & & 0.25 & $B$ & $\mathrm{D}$ & 0.38 & & & 0.39 & & & 0.55 & $\mathrm{~B}$ & & 18.8 & 4.92 \\
\hline 姿勢変化は楽にできたカ & 5 & -0.17 & & & 0.21 & & & 0.83 & & & 0.75 & & & 1.26 & & & 1.18 & & $\bar{D}$ & -7.0 & 4.69 \\
\hline リクライニング硬さ & 6 & -0.88 & & & -0.83 & & C & -0.38 & & & 0.13 & & & 0.00 & $\mathrm{D}$ & $\mathrm{B}$ & 0.09 & & & -20.8 & -6.48 \\
\hline 自分にとって & $6(2)$ & -0.33 & $\mathrm{C}$ & $\mathrm{C}$ & -0.42 & & & 0.38 & & $\mathrm{C}$ & 0.58 & & & 0.78 & & & 0.73 & & & -6.5 & 3.82 \\
\hline 肾ラライング調整しやすさ & 7 & $\infty$ & 5 & 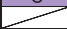 & 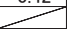 & 7 & 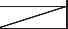 & 0.79 & $\mathrm{D}$ & $\bar{D}$ & -0.67 & & & 0.74 & C & & 1.14 & & B & & \\
\hline 座面のフィット感 & 8 & -1.17 & & B & -0.13 & C & & 0.46 & & & 0.25 & & & 1.00 & & & 0.91 & & & -6.4 & -0.26 \\
\hline 自分にとって & $8(2)$ & -1.00 & & & -0.13 & C & & 0.46 & & & 0.21 & D & C & 1.13 & & & 0.86 & & & -13.4 & 6.28 \\
\hline 背もたれのフィット感 & 9 & -0.54 & D & & -0.50 & $\mathrm{C}$ & & 0.17 & $B$ & & 0.63 & & & 1.04 & & A & 0.27 & D & C & -28.7 & -4.22 \\
\hline 自分にとって & $9(2)$ & -0.54 & $\mathrm{D}$ & & -0.57 & $\mathrm{D}$ & & 0.25 & & & 0.71 & & & 1.13 & & B & 0.27 & D & $\mathrm{D}$ & -40.3 & 0.58 \\
\hline 腰部のフィット感 & 10 & -1.17 & & B & -0.46 & C & A & -0.08 & & & 0.54 & & & 0.83 & & A & 0.45 & C & $\mathrm{D}$ & -28.9 & -5.84 \\
\hline 自分にとって & $10(2)$ & -0.92 & $\mathrm{C}$ & & -0.54 & $\mathrm{D}$ & & 0.21 & & & 0.46 & & B & 1.00 & & & 0.55 & $\mathrm{C}$ & & -32.7 & -5.68 \\
\hline 背の上部のフィット感 & 11 & 2 & 5 & 5 & 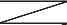 & $F$ & 5 & 7 & 5 & 2 & $=$ & 5 & 5 & 0.78 & & A & 0.36 & C & & 7 & 7 \\
\hline 自分にとって & 11(2) & & 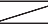 & 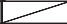 & & F & 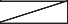 & & 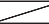 & & & 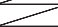 & 2 & 0.96 & & $B$ & 0.27 & $\mathrm{D}$ & & 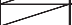 & \\
\hline さわり心地 & 12 & -1.00 & & C & 0.42 & C & & 0.75 & & $\mathrm{D}$ & 0.83 & & & 0.91 & $\mathrm{C}$ & & 1.09 & & & -14.3 & 8.43 \\
\hline 座面の幅 & 13 & -1.21 & & & -0.50 & $\mathrm{C}$ & & -0.29 & & & 0.58 & & $\mathrm{C}$ & 1.09 & $B$ & & 0.77 & $\mathrm{~B}$ & $\mathrm{C}$ & 4.4 & 6.65 \\
\hline 自分にとって & $13(2)$ & -1.08 & & & -0.13 & $\mathrm{D}$ & $B$ & 0.33 & & $\bar{D}$ & 0.58 & & $\bar{D}$ & 1.04 & & $\mathrm{C}$ & 1.00 & $\mathrm{C}$ & & -16.7 & 8.73 \\
\hline 座面の奥行き & 14 & -0.88 & & & -0.25 & & & -0.21 & C & & 0.00 & & & 1.22 & $\mathrm{~A}$ & & 0.91 & $\mathrm{~B}$ & & 11.7 & -4.45 \\
\hline 自分にとって & $14(2)$ & -0.61 & & & 0.13 & & & 0.29 & & C & 0.17 & C & $\mathrm{B}$ & 0.96 & & $\mathrm{D}$ & 0.81 & & & -8.4 & 3.17 \\
\hline 背もたれの幅 & 15 & -1.08 & C & & -0.58 & C & & -0.42 & $\mathrm{C}$ & & 0.67 & & $\mathrm{~B}$ & 1.22 & & & 0.95 & & $\mathrm{C}$ & -9.1 & 0.22 \\
\hline 自分にとって & $15(2)$ & -0.79 & $\mathrm{D}$ & $\mathrm{A}$ & 0.00 & & & 0.00 & $\mathrm{C}$ & $\mathrm{C}$ & 0.75 & & & 1.26 & & & 0.91 & & & -19.3 & -0.47 \\
\hline 座面高さの調整しやする & 16 & -1.17 & B & & 0.25 & $\mathrm{D}$ & & 1.08 & & & 0.29 & $\mathrm{D}$ & & 0.96 & $\mathrm{C}$ & $\mathrm{C}$ & 1.27 & $\mathrm{C}$ & $\mathrm{C}$ & -25.1 & 4.59 \\
\hline 背もたれ形状の合い具A & 17 & & $=$ & 5 & 0.17 & C & & 0.29 & $\mathrm{D}$ & & & 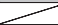 & $\pi$ & & $Z$ & T & $>$ & $=$ & 5 & 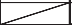 & \\
\hline 䔟動性 & 18 & -1.21 & & & 0.04 & $\mathrm{D}$ & $B$ & 0.50 & $\mathrm{C}$ & $B$ & 0.29 & $\mathrm{C}$ & & 0.96 & $\mathrm{~B}$ & B & 1.09 & & & -22.1 & -4.83 \\
\hline 自分にとって & 18(2) & -1.21 & & & -0.13 & D & & 0.58 & & & 0.29 & $\mathrm{C}$ & & 0.91 & & & 0.95 & & B & -22.2 & -2.65 \\
\hline 着座時の衝撃 & 19 & -0.79 & & B & -0.17 & C & B & 0.42 & & C & 0.04 & $\mathrm{D}$ & & 0.43 & C & $B$ & 0.64 & $B$ & & -41.6 & -3.25 \\
\hline 安定感 & 20 & -0.46 & & A & 0.08 & D & D & 1.00 & & D & 1.00 & & $\bar{D}$ & 1.39 & & $\mathrm{D}$ & 1.32 & & $\mathrm{D}$ & -16.9 & 20.74 \\
\hline 调整レバーの扱いやす & 21 & -1.08 & B & & -0.75 & & & 0.88 & $\mathrm{C}$ & $\mathrm{D}$ & -0.21 & & & 0.57 & & & 1.14 & & $\mathrm{C}$ & -2.1 & 9.30 \\
\hline 調整レパーの位置 & 22 & -1.13 & & & -0.50 & & D & 0.79 & & & -0.08 & & & 0.87 & & & 1.23 & & C & 1.8 & 6.46 \\
\hline 総合評価 & 23 & -0.92 & & & -0.08 & & $\mathrm{C}$ & 0.54 & & $\mathrm{C}$ & 0.58 & & $\mathrm{C}$ & 1.30 & & $\mathrm{D}$ & 1.00 & $\mathrm{C}$ & $\mathrm{D}$ & -10.8 & 16.72 \\
\hline 平均値が負評価である & 質問数 & 26 & 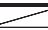 & & 19 & & & 5 & 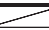 & & 4 & 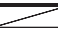 & & 1 & Z & & 1 & $E$ & $E$ & & \\
\hline 評価が低下した質汫 & 数 & & 9 & 6 & & 18 & 10 & & 7 & 11 & & 8 & 6 & & 7 & 6 & & 10 & 14 & & \\
\hline 評価が上昇した質閴 & 间数 & & 2 & & & 0 & & & 2 & & & 0 & & & 3 & & & 4 & & & \\
\hline
\end{tabular}

